\title{
ACCOUNTING ASPECTS OF THE SECURITIES ACT
}

\author{
T. H. SANDERs*
}

\section{The Act and Accounting}

The preamble of the Securities Act of 1933 opens with the statement that it is "An Act to provide full and fair disclosure of the character of securities sold in interstate and foreign commerce and through the mails, ..." Such 'a purpose immediately invokes the resources of accounting; the "character of securities" is in large measure revealed in the financial information about the company issuing the securities, as developed in its accounting statements. The history of accounting, ever since it became common for business to be carried on by corporations financed by public issues of securities, has been concerned with the problem of discovering what constituted "full and fair disclosure" and with providing the information which would satisfy the definition. The accounting requirements of the Securities and Exchange Commission are therefore the culmination of a long movement which has had in view the same purposes as those of the Securities Act, and any consideration of the accomplishments of that act would be incomplete without a survey of this historical evolution. In the language of the act itself, such a survey might be said to have "omitted to state a material fact required to be stated therein or necessary to make the statements therein not misleading," and, since this is one of the cardinal sins which the act seeks to prevent in registration statements, it ought also to be avoided in discussions of the act.'

\section{Historical Review of Accounting and Investment}

Açcurate and effective accounting does not flourish in a pioneer country, and until recently most of our people have been proud of the fact that this was a pioneer country. The British poet, speaking of the history of his own country, alluded to "our rough island story"; we have had a correspondingly rough continental story. The principal characters in it were men of immense vigor in action, and it was not to be expected that they would have a scrupulous regard for the niceties of accounting; on the contrary it was extremely difficult for them to understand the necessity for any accounting. The last $5^{0}$ years have seen a transition from this pioneering

- B. Com., I905, M. Com., I914, University of Birmingham, England; Ph.D., I92I, Harvard University. Professor of Accounting since 1927 at the Harvard University Graduate School of Business Administration; Associate Professor, 1924-1927, Assistant Professor, I921-I924. Consultant to the Securities and Exchange Commission, 1934-1935.

${ }^{2}$ Securities Act, ${ }_{\text {I }}$ (2). 
era to one of more settled and organized industry, which may reasonably be expected to live up to more orderly rules. As progress is made, however, it is not necessary to reflect too severely upon those who in an earlier day acted according to the conditions of their time. The change in the character of business has arisen in part from the change in the basis of financing. it; to an ever-increasing degree its securities have been offered to the public, in order that they might participate in what at one time was spoken of approvingly as "the democratization of industry." And now the Securities and Exchange Commission lays down its rules with the dictum: "A nation of investors deserves, at least, this slight protection."2

The first great public issues of securities in this country, other than governmental, were largely those of the railroads, and some of the earliest corporate reorganizations in which large blocks of security values were extinguished occurred in that field. Nevertheless the Interstate Commerce Act of 1887 was more a movement of shippers than of investors; shippers were much more numerous than investors, and since a considerable proportion of these securities was floated in foreign countries, it is not impossible that Congress was in part influenced by the fact that customers of the railroads were voters, while investors in them were not. In any case the Interstate Commerce Commission gave its early attention to rates, but also introduced accounting methods which gradually became a major factor in its public control. The same has been true of public utility commissions, and of federal and state bodies for the supervision of banks and insurance companies.

The United States Steel Corporation has, from its foundation in rooo, practised a high level of "full and fair disclosure," and has been followed by other industrial corporations. The New York Stock Exchange has not been indifferent to "the character of securities sold," but under the leadership of some of its officers has for years fought conscientiously for precisely those causes which in the Securities Act were taken up by the federal government. In these efforts it has been well supported by the public accounting profession.

What then were the weaknesses which made the Securities Act necessary? Broadly speaking, these agencies constituted an inadequate coverage of the problem, and in many cases did not have the requisite power to enforce their standards. Although railroad and utility securities represented a large segment in the financial activities of the nation, the commissions which supervised them necessarily left untouched the still greater areas of industrial, commercial, and financial securities. Other than the common law itself, with its general rules against fraudulent dealings, the exchanges were the principal bodies in a position to do something in the direction of improving accounting standards. Although the New York Stock Exchange was the most powerful of these, there were 35 other exchanges on which securities were traded in, and while some of these endeavored to follow the lead of the New York Stock Exchange, the majority of them were less concerned about the problems involved, or at least weak in their attack upon them. The New York Stock Ex-

' In re Haddam Distillers Corp., I S. E. C. 37 (I934). 
change itself could proceed only step by step, at such pace as it could make with the consent of the listed corporations. As more stringent accounting requirements were found to be necessary, the Exchange might be successful in inserting them in new agreements for the listing of new issues, but was not in a position to rewrite its existing agreements. Corporations could insist upon their contractual rights, and there was a lag in the extent to which the great body of listed corporations was under obligation to live up to the latest accounting requirements. Yet the Stock Exchange had some success in winning the general consent of the corporations to periodic movements which had the effect of raising the general level of accounting and reporting performance.

\section{Contribution of the Securities Act}

In these circumstances what contribution has been made under the Securities Act to the better public reporting of corporate financial condition? It must be remembered that, even when the published balance sheet and income statement gave only meagre summaries, omitted significant matters, or even made direct misrepresentation of financial condition, the internal records of the company were frequently sufficiently reliable and detailed to afford a true picture to those who had access to them. But this of course was the sort of thing which the authors of the Securities Act aimed to remedy, that privileged insiders should have one picture of the situation -a reasonably complete and true one, while the outside public had another pictureincomplete if not definitely erroneous. While many leading corporations were following a reporting practice which carried a high degree of reliability, in the sense that those who had only the published reports of the company saw the picture substantially as the directors and officers saw it, and no items which would materially change that picture were withheld, yet for the reasons already given other corporations failed to live up to this standard, and in their cases it has not been true that a complete and accurate picture of the company's finances was publicly available. The effects of the Securities Act have been, first, to strengthen the hands of all those who were already working for better accounting, placing them in a position to insist even more stoutly upon what they conceived to be called for by a high standard of reporting and, second, to bring all corporations coming within the sway of the Commission up to the level of the best. Thus reform and improvement were brought about, and in one step advanced to a level which would have taken years to develop if left to the voluntary efforts of private agencies. This was the objective sought for, and there is little doubt in the minds of those familiar with the work of the Commission that it is in fair way of realization. The investment banking community, which at first was so much alarmed by this legislation, has come to recognize that the general tone and character of their business has by it been greatly improved. The more responsible members of the profession have less fear that competitors will take business away from them by using less exacting standards of accounting, calculated to make the preparation of the issue cheaper for the issuer, 
and at the same time perhaps to enable the securities to be presented to the public in a more favorable light than they really deserved, by suppressing the more unattractive features of the company's status. Many members of the investment banking profession would be greatly disturbed if adverse court decisions should tend to destroy the salutary influences of the Commission.

\section{Two Classes of Corporations}

One of the most constructive policies adopted by the Commission was that which led it to distinguish between old-established, reputable corporations with a known position and newer, mostly smaller, promotions still in a speculative stage. There can be no doubt that the former group had been unnecessarily burdened with regulations aimed primarily at the latter group, though the two situations present problems of entirely different character. With the newer companies scrutiny must necessarily be severe, in some cases to the point of prohibition; but seasoned corporations cannot reasonably be dealt with in the same manner. The Commission early recognized this important difference when it made the newer and more liberal requirements of Form A-2 available only to the latter class of corporations, while those not yet having a record of accomplishment were still required to register on the more exacting and arbitrary Form A-r. That the Commission did wisely in making this distinction will be evident from a very brief study of the list of 129 registration statements as to which stop orders, consent-refusal orders, and withdrawal orders were issued between September 1, 1934, and June 30, 1935. Only one was submitted under Form A-2; a number were prepared on special forms, but the great majority were on Form A-r. Of the companies making these offerings, not more than one or two have anything approaching a national standing and reputation; practically all of them represent purely local ventures, and many were of obviously unsubstantial character. The traditional reputation of mining stocks for fantasy and delusion is well borne out by this list; and, to a certain extent, so is the remark frequently made by members of the Commission in its early months to the effect that no reputable company need be apprehensive about registration. This list of forbidden issues well illustrates the two distinct phases of the Commission's work. Corporations of good standing, with years of satisfactory history behind them, find the problem of compliance with the Commission's requirements a relatively simple matter; most of them have nothing to conceal, and it is a question only of compiling the information required, in form and substance acceptable to the Commission. But in the second group are many dubious and border-line issues, about which there is reasonable question as to whether a public offering should be permitted or not, and if permitted, there can be no question that full information of their hazardous and speculative character should be furnished to investors before they buy. In the future evolution of the Commission's financial requirements, it is altogether desirable that

s. E. C., Fnst Aws. REP. (r935) 67-70. The projects listed were, however, not all without merit, Something like $25 \%$ of the stop orders were subsequently lifted by the Commission upon the filing of proper amendments to the registration statements. 
this distinction be maintained, and indeed extended as far as possible. While, therefore, the Commission's task with newer promotions is predominantly police duty, with established corporations it is rather the constructive task of inquiring how situations generally sound may be presented in the most revealing light. In the latter area are included (I) problems which arise from the historical character of the balance sheet and (2) problems arising from those aspects of accounting which are largely a matter of the exercise of intelligent opinion. The two groups are not distinct; they overlap considerably, but form a convenient basis for discussion.

\section{Problems Arising from the Historical Character of the Balance Shect}

When Congress specified "a balance sheet as of a date not more than go days prior to the date of filing," which balance sheet must contain no untrue statements, or omissions likely to mislead, it doubtless was thinking of the balance sheet mainly as it is customarily described in its own heading, a statement of financial condition as of a specified date; in other words, a statement of present condition. But one of the dominant characteristics of this financial statement is the extent to which both asset and liability items are carried forward from one financial period to another. The result is a continuous and extensive overlapping; all balance sheets are greatly influenced by large transactions and outlays.of the past which have a bearing on the present and on long periods to come; similarly in every fiscal period many such transactions are undertaken, but their effect will not be exhausted within the current period, and a large part of the amount involved must be carried forward for pro ration over future periods. The balance sheet thus carries within itself the effects of all the financial and accounting policies followed by the company since the beginning of its history, just as a man's body is said to contain all the marks of his entire medical history since birth. In the quest for a true balance sheet, therefore, how far should the Commission insist upon review and correction of the past, not so much with the object of retroactive accounting, but rather in the interest of a true balance sheet for the present and for the future? A literal compliance with the statute might be construed to require such an overhauling of earlier history, but the plain facts are first, that such a procedure would have involved the Commission and issuing companies alike in an interminable morass of doubts and uncertainties surrounding past transactions reflected in present balance sheets; and second, that the beneficial effect of these mountainous labors would have been almost precisely nil. The Commission therefore did wisely when it availed itself of the wide discretion accorded to it in the act and cut its way through this Gordian knot by a few bold decisions. One of the general circumstances which tended to embarrass the Federal Trade Commission's administration of this act was that it did not take a similar stand on this issue.

\section{Property and Plant Accounts}

.The balance sheet required must show "all of the assets of the issuer, the nature and cost thereof, whenever determinable, in such detail and in such form as the

'Securities Act, Sched. A. 
Commission shall prescribe." This requirement immediately brings up the subject of the long-time property and plant assets, which are frequently the largest items in the balance sheets of industrial, mining, utility, and transportation companies. Every such company must make for itself working rules as to what expenditures upon property it shall charge to capital, thus increasing the property account in the balance sheet, and what it shall charge against income, thus increasing maintenance expense, reducing net income, and adding nothing to the stated value of the property. The converse problems arise when property is retired. Exactly how have the retirements been dealt with, and what subtractions have been made from the property accounts with respect to them? A third group of problems is continuously present in the basis and the rate at which these property assets are to be written off by process of depreciation. Everything which has been done with respect to all these matters since the inception of the company is reflected in the balances of the accounts which now appear in the balance sheet as property assets, with their corresponding reserves. In many cases the records of these past transactions have been destroyed; frequently errors on one side have been offset by compensating errors on the other, so that the present results are broadly correct. The problem is not only of the determination of facts, and a correct accounting for them, but also involves the exercise of judgment as to what is a sound treatment.

All of these problems arise, in endlessly various forms, in the quest for a correct statement of the assets "at cost." What then shall be done about the numerous valuations and revaluations of property in which cost has been abandoned, and the effort made to state property assets at somebody's conception of their present value? Where these valuations have synchronized with a reorganization, or the transfer of the assets to a different corporation, the new value might be construed as being the effective cost to the new owner, and thus satisfy the letter of the law. But then in numerous instances arises the question in which property was acquired not for a money cost but for a cost consisting of securities issued. It is a well-known fact that such securities, with their par or stated values largely within the discretion of the officers and directors issuing them, have been handed out far more freely than cash would have been, and no experienced person is under any delusions as to an identity between a security price and a cash price paid for properties.

In its search for a satisfactory solution to these various problems, one that it might conscientiously regard as fulfilling the spirit of the law, the Commission has taken a firm stand, based on one hand on what was practically possible, and on the other on a clear perception of the difference between form and substance. The Commission's original accounting requirements were embodied in the instruction book for Form 10, the form applicable to the Securities Exchange Act, but these same regulations were soon afterwards adopted, with the necessary modifications, for Form A-2, the Commission's new form under the Securities Act. This solution in effect consisted of the following steps:

IIsa. 
I. Property and plant items were required to be stated in the balance sheet with references to a Schedule II, to be attached. ${ }^{6}$

2. Schedule II listed the property by main groups and required for each group (a) the opening balance "at the beginning of the first period of audit" which "may be as per accounts," (b) additions during the year at cost, (c) subtractions during the year, (d) balance at the end of the year, being the amount shown in the balance sheet.

3. The requirement of opening balances at the beginning of the first period of audit as the first money column in Schedule II had the effect of avoiding a great many inconsequential questions with regard to the past history of the plant account. As to matters of real substance, however, in which the opening balances might turn out to be misleading, the situation was safeguarded in two ways, one being an action of the Commission, and the other an effect of the law. Having in mind the numerous revaluations which have taken place, mostly upward in the r920's and downward in the 1930's, and accepting to some extent the view frequently expressed by accountants of wide experience, the Commission added to its balance sheet requirements another set of questions under the title "Historical Financial Information,"7 in which the issuer is required to give particulars of any substantial revaluations of the plant assets which have been made by the company since January I, I922. The carliest registration statements coming before the Commission would contain income statements going back to January I, 1932, and therefore this supplementary question covered a ten-year period prior to that date. The result is that if the plant accounts represent anything other than cost, at least as regards the preceding ten-year period, what they do represent will be brought out. The other safeguard to the situation lay, as stated, in the law itself. If there should be any elements in the plant accounts not reasonably representing either a true cost or a true value of the property, and if this discrepancy could be construed as a misstatement of a material fact, then the parties to the registration statement would be exposed to the provisions of the act, first as to stop order proceedings, and next as to the liabilities there provided. If, therefore, the amount shown in the balance sheet for plant has anything unusual in its make-up, the issuers and their advisers are bound to give such explanatory description as will make the situation clear, even though this is not specifically called for in the regulations of the Commission: In fact, the regulations contain a clause to the effect that they do not purport to be exhaustive, that they constitute a minimum requirement, ${ }^{8}$ and that the company should furnish any other information necessary to make the description complete and true.

\section{Intangible Assets}

Following upon the requirements as to the assets of the issuer comes the clause "(with intangible items segregated)." This involves another problem which, now

- Instruction Book for Form A-2 for Corporations. 'Torm A-2, Question 45.

Instructions for Form A-2, General Requirements for All [Financial] Statements.

'Securities Act, Sched. A, par. 25. 
that the requirements are known, will be relatively easy to deal with hereafter; but in the past it has not been customary to make this segregation, and it is an almost impossible task to observe the distinction, on any reasonable basis, with respect to old properties. The typical situation, and the one which best reflects the difficulties, is that in which a parent company has acquired a majority of the capital stock of a subsidiary, at prices substantially in excess of the net book value of the subsidiary. Probably the subsidiary has no intangibles recorded in its own books, and the officers of the parent company completed the transaction on the basis of the estimated future earning power of the subsidiary and its expected value as a member of the consolidated group. But they did not expressly state whether the amount paid over and above the net book value of the subsidiary represented a new valuation of its tangible assets, or was invested in intangible assets, or partly both. In the then general level of accounting practices this was not at the time a culpable oversight, since the officers had no occasion to make any such subdivision of the purchase price for their own purposes; all that was necessary was to enter the securities in their own books as investments at cost. price in one amount. But later, in the preparation of a consolidated balance sheet, the problem confronted them of dealing with the excess amounts paid for the subsidiaries. If in the consolidation the excess amounts were eliminated altogether, then the resulting aggregate figure would represent only tangible assets at the cost or book value to the subsidiaries, unless the latter carried intangibles on their own books; but, if the more usual practice were followed of including the carrying value of the investments in the consolidated balance sheet, then it would be necessary to apply to the resulting aggregate property account an appropriate description, which usually took the form of some reference, in the detailed title under which the plant item was presented, to goodwill or other intangible assets.

The Commission dealt with this situation by requiring intangible assets to be shown as a separate item in the balance sheet, accompanied by a separate explanatory schedule showing the balance at the beginning of the period, the changes during the period, and the balance at the end of the period as appearing in the current balance sheet. But the instructions on this schedule stated that, if in the books of the issuer intangible assets had not been kept separate from tangibles, then the two might be combined in the balance sheet and in one schedule. This was no more than a frank recognition of existing facts; to have gone further and required a separation of the two items in all cases would have greatly enhanced the difficulties of preparation of the statements, would have kept alive the fears and apprehensions with which the original requirements were regarded, and would have resulted only in arbitrary figures which would have done very little to aid any investor in arriving at a clearer perception of the true condition of the business.

These difficulties were well illustrated in the case of the American Smelting and Refining Company, which in April, 1935, undertook voluntarily to make a separation 
of tangibles and intangibles hitherto combined. After reciting the penalties imposed by the act for false statements, and alluding to the option allowed to the company by the Commission's regulations, the directors and officers somewhat reluctantly concluded that they should make an effort to effect the separation, while intimating rather plainly that they were not too confident of the results. The company had been formed, they stated, by the acquisition of a number of going concerns, for which they necessarily had to pay something more than their net book values. All these properties were shown in the balance sheet for December 3r, 1934, in one aggregate sum described:

\section{Capital Assets:}

Property-Cost of plants, properties of subsidiary companies and additions and improvements, including patents, licenses, good-will and other intangible assets not segregated, less depreciation, ore depletion, amortization and property written off to profit \& loss and to obsolescence reserve $\ldots \ldots \ldots \ldots \ldots \ldots \ldots \ldots \ldots \ldots \ldots \ldots \ldots$ \$roo,228,929.97

A letter to stockholders dated April 3, 1935, stated that the only separate amounts for tangibles and intangibles which had hitherto had any actual existence were those arrived at by the Internal Revenue Department in determining taxable income. Since this department does not allow depreciation on intangibles, its natural bias is to state the tangibles at a figure as low as possible, which results in intangibles being correspondingly increased. Under this influence, the amounts arrived at for the American Smelting and Refining Company had been, for tangibles, \$52,087,099.26, and for intangibles, $\$ 48,141,830.71$. This then the officers decided to adopt as a basis for separation of the two classes of property; but, since the tangible property might in their judgment, which they referred to as "no more than an intelligent opinion," be reasonably valued at $\$ 100,000,000$, they did not care to exhibit so disproportionate a figure for intangibles in the balance sheet. This item they therefore proposed to write down from $\$ 48, \mathrm{I} 4 \mathrm{I}, 830.7 \mathrm{I}$ to $\$ 4,478,390.7 \mathrm{I}$, accomplishing this by restatement of capital stock.

It would be difficult to make out a case for these new balance sheet figures being more informative than the old combined figure for which they were substituted; but the company officers, acting under pressure and influence from two different departments of the Federal Government, did the best they could with a difficult situation. It remains to be seen whether the Securities and Exchange Commission will regard these separate figures as being sufficiently important to warrant regarding the action of the American Smelting and Refining Company as a precedent upon which it might insist more vigorously upon separation of the two amounts. It would seem that a reasonable view might well be that the new figures thus obtained are still more arbitrary than the old, that they add nothing to an investor's understanding of the financial condition of the business, and that the matter might therefore continue to be left to the discretion of company officers, in accordance with the present regulations. 
But here again the conditions surrounding old-established companies need not govern the treatment of new ones in process of setting up their accounts for the first time. With these the Commission has dealt in energetic and critical spirit, and has not permitted obviously intangible items to be reported as if they were bricks and mortar, or machinery. In the first place, a flimsy basis, arising out of stock issues or otherwise, was no more countenanced for intangible assets than for tangibles. $^{10}$ In the second place, promoters' fees for services, experimental costs, property held on lease, and organization expenses, even if reasonably valued, are not items of tangible property, but form part of the intangible category. When the transactions giving rise to these assets have occurred in the recent past, it is not possible to contend that the amounts spent on tangibles and intangibles are indistinguishable. ${ }^{11}$

\section{Division of Surplus}

The requirements for the balance sheet then proceed:

All the liabilities of the issuer in such detail and such form as the Commission shall prescribe, including surplus of the issuer showing how and from what sources such surplus was created. ...

This is clearly intended to bring about a separation of capital surplus, if any, from the earned surplus, a matter to which in many minds even more importance has been attached than to the separate property accounts, because of the relations of surplus to earnings on the one hand, and to dividends on the other. But this requirement also raises parallel historical difficulties and ends, if persisted in, in similarly arbitrary results, as appear in the property accounts. It is in general desirable that the amount of earned surplus be clearly shown and that other surplus, derived from capital transactions of various sorts, be separately stated. But we are again confronted with the fact that in many cases this has not been done, and could now be done only by a retroactive review of surplus which would involve judgments as arbitrary as those required for the separation of tangible and intangible property where they have long been joined. Herc again the Commission took a practical view of the case; it called for schedules which broke down surplus into its constituent parts, but then added: ${ }^{12}$

... however if, in the accounts of the registrant, separate balances for these are not shown at the beginning of the period of report, i.e. if the company has not, up to the opening of the third fiscal year prior to the last annual closing date, differentiated in its accounting for surplus as indicated above in (a) and/or (b) and (c), then the registrant may state the surplus in one amount.

${ }^{20}$ In re Haddam Distillers Corp., I S. E. C. 37 (1934); In re American Gyro Co., I S. E. C. 83 (1935); In re Franco Mining Corp., I S. E. C. 285 (1936); In re Great Dyke Gold Mines, Inc., Securities Act Release No. 954, Aug. 5, 1936.

"In re Unity Gold Corp., I S. E. C. 25 (1934); In re Haddam Distillers Corp., I S. E. C. 37 (1934).

${ }^{22}$ Instruction Book for Form A-2, Balance Sheet Instructions, Surplus. 
The legal advisers of corporations have been even more reluctant than the accounting advisers to undertake these arbitrary breakdowns, and to present the resulting figures as true statements of material facts. Since any such amounts could at best be based upon opinion applied to transactions and conditions which took place years ago, and have since been largely superseded by more recent events, lawyers were quite strongly opposed to their inclusion in registration statements, regarding them as vulnerable to suitors of malicious character.

Since it is a new idea to many people that there should be any difficulty in separating earned from capital surplus, it is worth while to point out precisely wherein the obstacles lie, as illustrated by the history and character of capital surplus. In the first place, a purely balance sheet conception of surplus makes no distinction between different kinds of surplus; surplus in this sense is the excess of assets over liabilities plus stated capital, no matter what its source. This definition of surplus derives a good deal of force from legal recognition, as well as some business and financial convenience. Only when one comes to study the modern income statement, yielding a figure of earnings as now strictly construed, does it become important to distinguish sources of surplus other than earnings so derived. The issue of capital stock at a premium, the sale of treasury stock for more than it cost, and restatements of capital stock which reduce the stated amount thereof and leave a balance to be transferred to surplus are all clear-cut cases of the creation of capital surplus, and proper accounting requires that they be so stated. When such transactions occur in future, there should be no question about their treatment.

But assume that a corporation had such transactions years ago and included the resulting credit balances in a general surplus account. If that surplus account had never since been touched, it would now be possible to separate these amounts of capital surplus wrongly added to general surplus. But if, as is altogether likely, dividends have since been paid and charged against the combined surplus, or other amounts have been so charged, in what proportions is it to be assumed that they were charged respectively against earned surplus and capital surplus, and in what proportions are the separate remaining balances supposed to be? This is the question to which only an arbitrary answer can be given.

The problem is still more difficult with capital surplus derived from the other principal source, namely, upward restatements of asset values. If such surplus has been combined with earned surplus, the same difficulty appears in apportioning subsequent charges against the general surplus; but a further and still more disconcerting difficulty arises, namely, the question whether the write-up really was, in whole or in part, an item of capital surplus. It is easily conceivable that a plant might formerly have been excessively depreciated, and its earnings and earned surplus thereby understated; an appraisal increasing the net book value of the assets would then be simply a correction of this situation and thus be properly a credit to earned surplus, thereby restoring it to the amount which it should have been. As a 
matter of fact, many appraisals do contain some element of this kind, but how much is again a matter of arbitrary judgment.

It is a natural proposal that in such cases the old general surplus shall be carried forward, and that hereafter there shall be a separation of capital and earned surplus. But this would result in three surplus categories, and again the question arises as to how subsequent dividends and other surplus charges shall be apportioned among them. Reflection upon this difficulty is usually sufficient to deter any experienced person from seriously proposing this course; an arbitrary division is more practicable.

\section{Consolidated Statements}

Another series of problems calling for the serious consideration of the Commission was that arising from the common practice of issuing consolidated statements. Throughout the development period of our great corporations it has been felt that certain legal advantages, as well as considerable managerial and administrative conveniences, might often be secured by having the different operating units separately incorporated. While tax considerations have been a factor in determining the precise legal forms-in most cases the perfectly proper desire to avoid multiple taxation by different states, yet the managerial advantages have heen a still more potent reason. Where the entire group of corporations constitutes practically a single unified business, of which the member corporations are but branches, it is universally recognized that the consolidated balance sheet and consolidated income statement are the appropriate vehicles for describing its financial condition and earnings. But recent legislative changes have had the effect of placing heavy additional burdens on such consolidations and have caused many corporate managements to review the question of the advantages to be derived from separate incorporation of operating units; if the present trend continues, it seems likely that many hitherto separate legal entities will be merged. While the regulations of the Securities and Exchange Commission have not perhaps been the greatest influence in this direction, yet they have been contributory. The essential thesis of the Commission has been that, in so far as any of these component corporations are separate legal entities with their own individual financial and legal obligations, the consolidated statements should not be used in such manner as to conceal important elements in the financial condition of any one of them. The Commission's regulations have therefore been designed to bring out the financial condition both of the issuer of new securities and also of the consolidation of which it might be a part. If, therefore, the issuer is a parent company or a subsidiary, its own corporate statements will be accompanied by the still more informative consolidated statements; the regulations prescribe what is required in respect of them, and it is specified that the basis on which the common intercorporate relations have been accounted for must be stated. These include the handling of intercompany sales, intercompany profits, and the disposition of the difference between net book values of subsidiaries and the amounts at which they are carried in the parent books; the accounting practices of the parent 
in the matter of accruing in its own books the earnings or losses of subsidiaries, intercompany dividends, and the treatment of a subsidiary's initial surplus at the time of acquisition are also matters which must be explained.

An example illustrating the Commission's policy with respect to consolidation is found in the Baldwin Locomotive case, ${ }^{13}$ in which the Commission criticized the company's procedure with respect to its consolidated balance sheet. Following upon the omission by the company of its interest payments on bonds in the sinking fund, and the subsequent collapse of the market prices of its bonds, the Commission held an investigation into the circumstances preceding this event, and inquired in particular into the question whether it had been in any. way foreshadowed in the company's financial statements. It transpired that the very satisfactory current position of one subsidiary had, in the consolidated balance sheet, the effoct of concealing the fact that the parent company's current position had been somewhat impaired. The Commission's comment was to the effect that, since the resources of the subsidiary were not available to the parent except in so far as dividends might be declared, it was a mistake to convey the impression that those resources were in fact available for the bondholders of the parent, and that the situation called for a parent balance sheet in addition to the consolidated balance sheet. The company doubtless felt that it had complied with the rules of public reporting, at any rate as they had been commonly practiced up to that time. When the standards of conduct are in process of being raised, somebody always becomes the first victim of the change in the rules.

\section{Problems Arising from Judgment Element in Accounting}

Having thus reasonably deale with the problems of inherited conditions in the historical sections of the balance sheet, the Commission turned to those aspects of accounting, often too little appreciated, in which judgment must necessarily play a large part. In very broad terms, these problems consist mainly in the determination of the amounts which may from time to time be carried as assets in the balance sheet, and at what points they become proper and necessary charges against income. Thus the all-important question of income determination is conditioned to a marked degree by intelligent and honest judgment, requiring an extensive knowledge of general business conditions in that area, and of the effects on the financial policies of the corporation of one accounting practice as compared with another. For any government agency to enter this field with rigid prescriptions is to intrude unduly upon the management of the corporation itself, and can have only the results of the proverbial bull in the china shop. Who can prescribe a depreciation policy for a corporation, without knowing its practices with respect to maintenance, and its risks of obsolescence? Or who can determine an inventory valuation policy without an understanding of the conditions of raw material supply, cost accounting practices, and marketing problems of the particular company?

Securities Exchange Act Release No. 167, April 11, 1935. 


\section{Disclosure Prescribed-Not Methad}

A careful examination of the present accounting requirements under the act, as embodied in Form A-2 and the accompanying instruction book, will reflect two basic principles which the Securities and Exchange Commission has adopted, to the relief and satisfaction of registering companies, and at the same time to the increase in effectiveness of the work of the Commission. The first of these principles was that the Commission would not seek to dictate the accounting practices of business corporations in all those matters in which differences of personal opinion and differences of circumstances have shown that optional treatments are permissible and necessary. Acting upon this principle, the Commission has in its accounting regulations not sought to prescribe accounting methods, but has prescribed full disclosure of whatever accounting methods the company had chosen to adopt. The detailed instructions for nearly every item of the balance sheet and income statement contain either optional treatments, or else a requirement for the statement of whatever basis the company has acted upon; examples are so numerous as not to call for citation. Sometimes, while still allowing room for discretion, the regulations state or imply the Commission's preference, such as: "If reacquired stock (treasury stock) is shown as an asset in the balance sheet, give the reasons therefor and. ..."14 Under Capital Stock appears: "Reacquired stock (treasury stock) is preferably to be shown as a deduction from capital stock...." The general character of the regulations is much colored by the provision: "The registrant may file statements and schedules in such form, order and using such generally accepted terminology as will best indicate their significance and character in the light of the instructions." ${ }^{\text {"1s }}$ The second principle followed was that the Commission endeavored to relate its accounting requirements to the general accounting practices of business corporations, so far as these could be ascertained and generalized. Probably the chief respect in which the older accounting requirements of Form A-x constituted an unwarranted burden on business was that at too many points they took too little cognizance of the steps by which accounting information is in practice ordinarily classified and accumulated for the company's own purposes. Questions were asked in a few words, with simple and ingenuous air, which ran crosswise of the customary processes of accounting compilation, with the result that they could not be answered from figures available in the company's books, but imposed new and additional accounting classifications and summaries. Nor is it to be supposed that these new accumulations of data, hitherto ungathered by the corporations, represented additional and valuable financial information which had been overlooked; on the contrary, they resulted in material which either was of very little value, or which, when it had value, might be much more usefully presented in the form which had already been customary, and which the accounting records of the company had been designed to furnish. After the original alarm created by the insistence on civil and criminal

"s Instruction Book for Form A-2, Balance Sheet Instructions, Investments.

12Id., General Requirements for All [Financial] Statements. 
liabilities of issuers and their advisers, undoubtedly the next greatest concern was felt in connection with the new internal accounting burdens thus imposed. The new Commission's announcements at the time of the release of its accounting regulations intimated that it had consulted corporation officials and public accountants extensively, and the improvements in the accounting requirements in this respect reflected the substantial advantage which had thus been reaped. Corporation accounting officers have not omitted to express their appreciation of the discretion thus left to them.

\section{Auditors' Certificates}

The exercise of judgment is a conspicuous element in the certificate in which the public accountant who has reviewed the corporation's statements expresses his opinion of them. The functions of the outside auditor have not been too clear in the public mind; ideas about the detection of fraud and peculation have overahadowed the far more important constructive purpose of the presentation of a clear and reliable picture of a company's financial condition. The auditor's certificate is primarily an evidence that an independent mind has reviewed the company's statements and has concurred in the representations there made, or has dissented as explained.

There was at first some disposition on the part of the Commission to specify a form of certificate for the use of public accountants, and support for this course seemed to be implied in the adoption by the Committee of the American Institute of Accountants on Cooperation with Stock Exchanges of a form of certificate for recommendation to the notice of auditors of companies listed on exchanges. But it. was pointed out that it was one thing for the public accounting profession to discuss and recommend desirable practices, and something quite other for a government body to prescribe those practices with statutory force, and thus in part inhibit the use of that very judgment the public accountant was supposed to contribute. The view prevailed that the public would be served with more helpful opinion if the auditor were left to express himself in his own way, and that since he was to be held liable for what he said, it was not quite reasonable to put the words in his mouth. But the matter was not left entirely oper; the Commission outlined the subject matter to be covered in the certificate, and insisted that the auditor's opinion should be candid and complete.

The chief debatable ground between the Commission and the public accounting profession lies in the question: Granting that the public accountant's function is to furnish his opinion, how far should he go? In particular, how far should he go in criticizing the company's presentation? It is perhaps a natural view to suppose that the more criticism is supplied, the more light will rest upon the subject; but that is another maxim that does not work out as it appears. The ideal is the certificate without qualification, meaning that all the points which have come up for

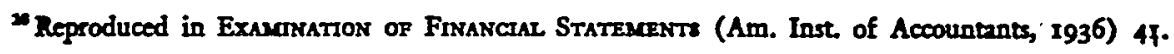


discussion during the examination have been settled to the mutual satisfaction of the company officers and the auditors. A balance sheet and an income statement are thereby offered to the public which, in the joint opinion of both, are the clearest and most helpful statements that can be presented. As soon as qualifications by the auditor appear the outside reader is left somewhat in the position of arbiter with very little to go upon in arriving at a judgment between the two. While, therefore, it is the auditor's duty to report any matter of moment in which he may wish to qualify the company statements, he will prefer to refrain from clouding the picture with disputation about less important matters. In drawing the line he can but fall back upon his own judgment, aided by the Commission's definition of a material fact. ${ }^{17}$

\section{Commission Influence on Accounting Statements}

What influences have been exerted by the regulations and by their subsequent administration? There can be little doubt that they have gone a considerable distance in fulfilling the purposes of the act in developing a more faithful and complete reporting of financial condition. In so far as there were cases where promoters.and others were disposed to be something less than conscientious in the preparation of statements, the regulations have added a little stiffening to their consciences; and where accountants have sought to do their full duty as faithful witnesses, the regulations have made them more effective in standing up against those influences which, innocently or not, have tended to color, exaggerate, or suppress. In other words, they have undoubtedly been brought a step or two nearer the fulfillment of their functions as accurate and impartial reporters of the truth about corporate financial condition, which must, however, be read in the light of what has elsewhere been said about the inescapably relative character of such truth. But three things at any rate may be pointed to as examples of the effects of the regulations, in addition to the raising of the general level induced by the complete specification for public reporting which the regulations as a whole constitute. The first of these arises in the balance sheet; the second relates to property valuations in the balance sheet; and the third concerns the income statement.

\section{Changes between Balance Sheets.}

In any balance sheet filed with the Commission, the regulations are designed to bring out all important factors, and not leave significant items concealed by combination, offset, or inadequate description. Still more, since it is commonly recognized that the changes between balance sheets are frequently of more significance than the items in a single balance sheet, the more important of those changes are analyzed by means of the schedules required to be attached to the balance sheet. The net changes, of course, were always available to any person who compared two succeeding balance sheets, but, by requiring both additions to and subtractions from

\footnotetext{
"Instruction Book for Form A-2, Definitions.
} 
the beginning balances, the full character and extent of the changes is brought to light. These schedules relate to the property and plant items, to the intangible items, to investments in marketable securities and for control, and to surplus. Not only do they bring to light the extent of the changes in these items, and any unusual transactions connected with them, but also, in so doing, they supply further information about company policies on such things as maintenance, and provide more information than has hitherto been available on cash requirements for plant purposes. In other words, they add to the picture of what some call the dynamics of the business. Here again it is fair to say that in so far as this information has been significant it has already been furnished by the larger and better reporting corporations, either as footnotes to the balance sheet, in appended schedules, or in the president's narrative report. The effect of the regulations is to make this practice general for all who come within the operation of the Securities Act.

\section{Income Statement Developments}

In recent years the importance of the income statement has been increasingly recognized, and, by requiring a more extensive income statement than has hitherto been generally available, the Commission has sought to insure that reported earnings shall be arrived at as soundly as possible. Opening with the amount of gross sales, followed by the cost of goods sold, the regulations require that a number of items in which public interest is considerable shall be separately set forth, either in the income statement or in Schedule VIII, or in both. The schedule is designed, moreover, to give flexibility to the situation so as to comport with whatever accounting practices the company may have followed. There is, for example, greatly varying practice as to whether the items of depreciation, maintenance, interest, insurance, and rents and royalties are included in cost of goods sold, or stated later as financial deductions, or charged in part to selling and administrative expenses. Schedule VIII is designed to accommodate itself to any or all of these different conditions. Income from sources other than operations, and non-recurring income, together with the corresponding expenses, are required to be separately stated, as called for in the law. ${ }^{18}$ The net result is that it would take something of daring and deliberate misrepresentation to conceal any important feature of the earning statement, or make it look materially different from what it should be.

The tendency to greater exactitude in the statement of income is illustrated in the prospectus issued by Shell Union Oil Corporation, dated March 10, 1936, in which a change of accounting practice was announced. Certain amounts arising from retirement of debentures, which had been charged or credited to income account in the published annual reports, were in the prospectus shown as surplus charges or credits. The same type of thing appears in the prospectus of Jones \& Laughlin Steel Corporation, dated April 2, 1936; though in this case a change of auditors may have had something to do with the change in accounting practice, it

\footnotetext{
${ }^{25}$ Securities Act, Sched. A, par. 26.
} 
is reasonable to suppose that the Commission regulations were the greater influence. Probably investment trusts also will be more generally disposed than hitherto to keep their income accounts free of capital or non-recurring gains and losses.

This question of the line to be drawn between the income account and surplus will of course be a perpetual one. It is to be hoped that the Commission will stick to its requirements of full disclosure of all unusual surplus charges and credits, but again it will do well not to lay down too rigid rules. In the first place, no rule can be satisfactory in all cases; in the second place, there is something to be learned about a company and its management from the kind of accounting they do when left to themselves, provided their accounting can be clearly seen. This is especially true of a practice like the base stock inventory method, which implies a conservative and long-range view of income determination, and of charges to surplus rather than to income, which tend to imply the reverse.

\section{Property Accounts in Commission Decisions}

Property and plant valuations have received a good deal of attention in the Commission's decisions and opinions, ${ }^{10}$ and, while the Commission has shown itself disposed to give reasonable weight to accounting opinion and authority, it has not been willing to acquiesce in extravagant valuations based chiefly on legal technicalities connected with stock issues, and having little of substance about them. The prodilection of promoters for issuing stock in round sums, and then valuing property at any amount required to balance, has been discouraged in the most vigorous terms, and so have the more fanciful speculations of appraisers. Disclosure of the basis of property values has been insisted. upon, and properties "at cost" have been required to show substantial consideration, so that stock selling in cash transactions at a nominal amount per share has not been admitted at much more substantial sums as a basis for property values. ${ }^{20}$ While recognizing that many aspects of accounting call for reasonable judgment, the Commission has rejected the idea that reasonable judgment includes the suppression of known facts; ${ }^{21}$ and, if in the exercise of judgment such items as the costs of planning, surveys, taxes, insurance, permits, engineering fees, interest, and specifications have been included in the cost of a building, then the reasonable consequences of this decision must be faced, and these charges depreciated together with the building. ${ }^{22}$ Even when property has been stated "at cost," a much higher appraisal figure, tending to imply that the cost valuation was conservative, was not admitted when the appraisal itself turned out to be questionable.23 Appraisals of water supplies based upon alternative sources of water, when nobody would in fact think of using those alternative sources, and when the actual cash outlays were only a small fraction of such appraisals, have been

\footnotetext{
- See Volume I of the Decisions of the Securitics and Exchange Commission and subsequent releases.

- In re Unity Gold Corp. I S. E. C. 25 (1934).

- In re Big Wedge Gold Mrining Con I S. E. C. 98 (1935).

II re Continental Distillers and Importers Corp., I S. E. C. 54 (1935).

Ibid.
} 
rejected. ${ }^{24}$ In the field of mining engineering it has not been regarded as a proper exercise of judgment to base valuations on extravagantly optimistic estimates, while suppressing all mention of other (and apparently more accurate) tests which indicated very little value in the property. ${ }^{25}$ In many of these cases promoters. figured. as simultaneous buyers and sellers of property, a situation always provocative of doubts, and the Commission has examined them with candor and penetration.

\section{Criticisms of the Commission's Accounting Policies}

Criticism of the accounting requirements of the Commission has taken four main lines: first, that while the printed regulations are in general broad and reasonable, the administration of those regulations by the Commission's staff is less so and in some instances descends to trivialities; second, that while the information thus elicited may be of value, even of considerable value, this is not sufficient to justify the great cost and burden of producing it; third, that some of the information required is of confidential character, and should not be publicly disclosed by the Commission; fourth, that these things are better left to work themselves out, without the intervention of the government. These objections will, therefore, be considered in order.

\section{Administration by Federal Trade Commission}

It is not necessary here to discuss the accounting phases of the somewhat abortive administration of the act, before it was amended, by the Federal Trade Commiscion. Whether the act itself stopped the flow of new issues, or whether the stoppage was solely the result of the depression; whether the burden and expense of preparation of registration statements really were prohibitive, or whether corporation officials and their legal and accounting advisers were swayed by baseless fears and magnified their own difficulties, are questions which as a practical matter it is unnecessary to answer now. Undoubtedly something of all these elements was present. The fact that the act was amended is admission by its sponsors that the original requirements were unduly severe. As to the preparation of registration statements, it is unquestionably true that the few which were prepared before the transfer of administration to the Securities and Exchange Commission were prohibitive in financial cost, and still more so in respect of the human effort which went into them. It would have been quite impossible to do any. considerable amount of business on such a basis.

\section{Administration by S. E. C. Staff}

There is probably some truth in the charge that the Commission's staff is less flexible than the Commission itself might wish; this is a result almost inseparable from any large administrative task, since juniors cannot be granted, nor are they willing to assume, as much discretion as their seniors would probably use. Cases are cited in which valuable time is consumed upon trivial details, and although such

\footnotetext{
an In Haddam Distillers Corp., I S. E. C. 37 (1934).
}

-In re Big Wedge Gold Mining Co., I S. E. C. 98 (1935). 
insistence is exasperating, it is less important than its almost inevitable accompaniment that the staff may overlook more significant matters. As a matter of fact, while the Commission states that its accounting requirements constitute a minimum of information to be supplied by registrants, in a very real sense they also establish a maximum of demands which the Commission may make upon business.

Of much more moment are the implications of an announcement such as:

"Allis-Chalmers Manufacturing Company will be asked by the SEC to amend the financial reports submitted in its permanent registration application early this year to conform with the reports filed under the Securities Act registration last week."26

It may be presumed that the "permanent registration application" was Form ro under the Securities Exchange Act. In the accountants' certificate included in the prospectus issued by this company on November 6, 1935, it was stated that certain adjustments, enumerated and explained, had been made in the profit and loss statements there given, which therefore differed "from the net results shown in the registrant's annual reports to its stockholders heretofore published." The description develops that these adjustments consisted of redistributions of amounts as between individual years from 193I to 1934 , but did not affect surplus at December 3I, 1934. Presumably the statements incorporated in Form to were similar to those published in the company's annual reports, but under the more exacting requirements of the Securities Act the period had been reviewed and these adjustments made in Form A-2. It will frequently happen that any review of a series of years will in the light of results develop adjustments of this character, and these adjustments, especially when they affect profit and loss, may have some bearing on the value of a new issue, even though the aggregate result for all years is the same as before. The Commission is entitled, and indeed obligated, to require an explanation of these adjustments. But as regards the annual reports to stockholders, that for December $3^{1}$, I935, announced the adjustments in terms practically identical with those of the prospectus, after which there was no occasion to attempt to restate the annual reports already issued. Apparently, therefore, the only question raised was whether it was sufficient for Form to to give the annual statements as furnished to stockholders or whether it should contain the same adjustments as shown in Form A-2.

This question of restatement of financial reports already published came before the Commission in the case of Northern States Power Company, ${ }^{27}$ in which the Commission voted three to two to accept certain explanations as to the treatment of bond discount in past statements, without requiring restatement of the past balance sheets, earnings, and surplus accounts. The Commission should continue to resist this tendency to require restatement of accounts which have already entered into

\footnotetext{
Wall Street Journal, Oct. 23, 1935.

${ }^{27}$ Securitics Act Release No. 254, Nov. 21, I 934.
} 
the public record. The Allis-Chalmers adjustments were far less serious than those in Northern States Power; the former were probably such as could be determined only from review after the event, while the latter contained features which could scarcely have been regarded as other than questionable accounting at the time they occurred.

The important point is that it is far more illuminating to let the record stand, and state plainly wherein it was at fault or subject to modification, than it is to attempt restatement of the original record. The latter procedure can only result in endless confusion; it is time-consuming and expensive, and the results are less helpful to investors than those of the former course.

On the other hand, it seems to be the Commission's policy to adapt its. procedures to the exigencies of particular cases. This is shown in its practice of bringing out special forms for special industries, in order to deal effectively with them and yet avoid burdening other industries with requirements with which they are not concerned. In this way the Commission will tend to maintain a greater flexibility in its administration.

The burden of preparation of registration statements and prospectuses is still considerable, but much less than it used to be. The preparation by old-established companies of registration statements on Form A-2 has largely settled down into a routine; company officials and accountants know what is expected of them and have adapted their accounting practices to the requirements. In the space of three years the transition has been made from a condition in which the preparation of a registration statement was an agonizing procedure to one in which it has become a normal event taken more or less ir stride. The schedules attached to the balance sheet and income statement are apparently the feature most complained of on this score. They frequently involve extra work, over and above what would be undertaken but for the Commission's requirements, and are especially arduous for large consolidations. 'An alternative, as regards the plant schedules, would be for the information to be furnished in narrative instead of tabular form and to give only the substance of the changes. In the form of narrative such information has been regularly furnished by a number of companies in their annual statements; but the account analysis in tabular form is more formidable to readers. Doubtless the Commission's viewpoint is that it desires a complete accounting between the beginning and the end of the period, but this is one place in which there is an opportunity to do something both to reduce the burden of work and also to present the information in more usable form. It should be possible to do this with proper safeguards that nothing important will be omitted. But mention of the point is indicative of the scarcity of criticism of the requirements from the point of view of the burden they impose. 


\section{Confidential Information}

The Securities Exchange Act authorizes the Commission ${ }^{28}$ to hold confidential any information which, upon application of the registering company, the Commission shall consider to be deserving of such treatment, provided it can be done without injury to the public interest; notice of this was accordingly inserted in Form 10. The anxieties of issuers have been aroused most by the requirements that they state the amounts of sales and cost of goods sold on the one hand, and salaries of officials on the other; the most common requests for confidential treatment have therefore been concerned with these items. At first no such provision was contained in Form $\mathrm{A}-2$, but an amendment ${ }^{2 \theta}$ provided that any company which had been accorded confidential treatment under the Securities Exchange Act for the items Sales and Cost of Goods Sold might omit those items in Form A-2.

The chief source of fear arising from the publication of sales, cost of goods sold, and gross margin has been that powerful competitors or powerful customers might use the information to the injury of the company. It has frequently been argued that the showing of a too prosperous-looking gross margin would attract unwelcome competition to the field. The argument gains additional force where the company manufactures only one main line of goods, with which the gross margin can be identified; if a heterogeneous line of goods is manufactured and sold, the information as to gross margin is less informative to an outsider.

The detached and unbiased person will find some difficulty in coming to a conclusion on this subject satisfactory to his own judgment. He is bound to have some sympathy with the anxieties of business men who feel that they are being placed in a more exposed position than ever before and that the information sought as a protection to their stockholders is in fact a menace to them; it is not a satisfactory solution merely to make light of their difficulties. That the Commission has lent a sympathetic ear is clear from the fact that during the year ended June $3^{\circ}, 1936$, it has granted confidential treatment to $2 \mathrm{I}_{4}$ items of information filed by 162 issuers; applications were received from $63 \mathrm{I}$ issuers for confidential treatment of 966 items. These would all be under the Exchange Act. But a careful consideration of numbers of cases in which this treatment has been claimed leads to the conclusion that, from the public point of view, the requirement for disclosure is in general a reasonable one, and that the Commission has done well to insist upon it as part of the income statement. It is true that the sales figure alone is of little value to those studying the company's position, but the same might be said of almost any single figure in the balance sheet or income statement, with the possible exception of the net profit figure itself. Practically all individual items are merely contributory to the general impression which it is sought to obtain. Security analysts claim that they make much use of the comparative sales from year to year, especially in computing the proportion of increased sales which comes through as net profit. This is the

* Securities Act, $\$ 24(b)$.

" Securities Act Release No. 930, July 30, 1936. 
sort of information which has sometimes been characterized as being more useful to speculators than to investors. The Commission may well continue to accord confidential treatment in those cases in which the circumstances seem to justify it; there undoubtedly are instances in which disclosure would do more harm than good.

\section{Public Policy}

The most fundamental objections to the accounting requirements are of course those arising from a political philosophy at variance with that upon which the act is predicated. Those who hold that it is none of government's business to intervene in these matters and that investors will learn faster from getting their fingers burned than from spoon-feeding with even the most reliable information will necessarily have difficulty in accepting the machinery of the act. There is more to be said for this viewpoint than is commonly supposed; but as a practical matter everybody recognizes that the question is one of degree, that in the present mood of the people government cannot abdicate the office of umpire, that what seem like extensions of government function are in part government's attempts to keep pace with the increasing complexity of economic life, and that the problem consists in keeping all these forces in as just a balance as possible. Responsible accounting opinion has almost everywhere approved the fundamental conceptions of the Securities Act, but has bent its effort in the direction of making its provisions more effective by keeping them within temperate bounds.

\section{Utilization of Information by Investors}

The extent to which the financial information elicited by the Commission is utilized by investors and its value to them are matters on which there is much dispute. The benefits accrue largely by indirect and imperceptible process, which does not permit any close relating of investment action with specific disclosures. Information developed under Form A-2, concerned as it usually is with old-established corporations, does not as a rule add anything of great moment to the information already available on the same companies. From financial statements previously published, intelligent investors are already apprised of the company's record of earnings over a period of years, of its current position and general financial strength; they have formed fairly definite impressions of the capacity of the management, of the future prospects of the company, and of the industry to which it belongs. Sound investment opinion is a plant of slow growth; it cannot be created instanter, and draws support from all sorts of sources outside the limits even of Form A-2. From such considerations it is easy to argue that registration statements have as yet added very little to the sum of essential investment information.

With newer and more hazardous promotions, on the other hand, the registration statement and prospectus prepared under the Commission's rules undoubtedly furnish more, and more reliable, information, than has commonly been hitherto available. But the buyers of such securities notoriously do not act upon careful analysis; 
they act upon hunches, the tips of friends, the specious representations of salesmen, all sorts of motives except deliberate consideration of sound information. In so far as they may be disposed to do a little serious analysis, however, they are being provided with far more information, of a far more genuine stamp, than they have had before, and it is reasonable to suppose that this is likely at least to induce in promoters a greater sense of responsibility, even if the more gullible kind of investor seldom reads their frank revelations.

Among those responsible for the dissemination of financial information, some disappointment is expressed with the degree of interest with which the additional material has been received. It is asserted that too many investors are content to observe and follow the trends; , that the generally upward trends since the passage of the Securities Act in 1933 have been the basis of security buying; and that individual security analysis has been proportionately less searching. There can be no doubt that there is much tendency in the direction stated.

\section{Liabilities for Accounting Information}

Consideration of the accounting problems involved in the public reporting of company financial condition and earnings induces reflection upon the liabilities imposed upon issuers and accountants with regard to financial statements. How far do the liabilities now attaching to the makers of financial statements coincide with the responsibilities which they may reasonably be expected to carry, and what policies with respect to them does the public good seem to demand?

A free flow of capital into business, both for developing new industries and for expanding old ones, is eminently in the public interest. It is no denial of this fact that speculation sometimes becomes unreasonable and disastrous, but such occurrences point to the need for some form of regulation.

It is inevitable that many ventures will not turn out to be financially successful. Public policy cannot therefore undertake to guarantee a happy outcome for all investments, but should tend to encourage discrimination among investors as to the types of security they buy. In particular, small investors should be encouraged to commit their savings to places subject to some form of public supervision, including the various categories of government bonds, insurance of all kinds, and savings banks.

In so far as the public does invest in industrial securities it is desirable that the issuers should furnish such information as will enable the character of the securities to be judged with some degree of assurance and that there should be a government agency to see that this be done.

But the general tendency to regard financial statements as statements of absolute fact should be recognized as being itself somewhat delusive, and regulation should seek to adjust the balance by taking cognizance of, and seeking to make more widely 
understood, the extent to which accounting statements are matters of fact on the one hand and matters of opinion and judgment on the other.

The Commission advances the definition of these problems when it reserves its condemnation for such things as the showing in financial statements of "values beyond any maximum that differences of opinion might condone."30

The liabilities of issuers have not only been increased by the Securities Act, but have also been widely advertised by public discussion. It is generally apprehended that when the next great collapse in security prices occurs, many suits to recover losses will be brought by disappointed losers. It will then be necessary that the courts, to do justice in individual cases and to further the wisest public policy, should give full consideration to:

a. The essential character of financial statements, especially the extent to which they are respectively matters of fact or matters of opinion and judgment.

b. The natural tendency to make ex post facto judgments and to read into statements interpretations which could not have been formed at the time the statements were prepared.

c. The tendency of juries to sympathize with losers, especially with losers at the hands of corporate finance.

The areas within which controversy will arise will include:

a. Actual facts stated in the balance sheet and income account. On these, for the most part, responsible company officers and their accounting advisers will, with ordinary care, be able to furnish information to the reasonable satisfaction of the public and without too much risk for themselves.

b. Omissions of material facts. The definition of material facts can never be specific and exhaustive; references in some prospectuses to possibilities of inflation, foreign invasion, or other political disturbance suggest the range of conjecture. The courts will be confronted with the problem of determining how far the event might reasonably have been expected to be foreseen at the time of issue and to what extent it was culpable negligence to omit mention of the fact, if foreseen.

c. Matters in balance sheets and income statemerts which call for the exercise of judgment and on which a plaintiff, prompted perhaps by subsequent events, has placed an interpretation differing from that embodied in the statements.

d. Admitted misstatements of financial fact, about which the large question then is whether, and to what extent, they caused the plaintiff's loss.

Unless the law gives full weight to the foregoing considerations, it will be inevitable that forces tending the other way will bring about serious miscarriages of justice.

It is not desirable that accountants should, in pointing out these problems, go the

* In re Haddam Distillers Corp., I S. E. C. 37, 46 (1934). 
length of minimizing the important part which financial statements play in investment activities. They constitute essential elements in the structure of information upon which judgments are formed, first by the underwriters, and second by large investors and statistical agencies who also examine with care the information furnished.

Three questions arise, with reference to financial statements alleged to be misleading: ( $\mathrm{r}$ ) whether there is liability or not; (2) to whom there is liability; (3) the amount of the liability.

x. When the defence is allowed that those who prepared the statements (a) had made reasonable investigation, (b) had reasonable grounds to believe, and (c) did in fact believe that the statements made were true and complete, it does not seem that the burden of proof here imposed upon defendants is unduly heavy.

2. For issuers and accountants to deny any responsibility to the considerable army of investors who act not directly on their own knowledge and judgment but on the judgments of intermediaries in whom they have placed confidence seems out of step with the general trend of the law, which is disposed to hold a producer responsible to his ultimate customer through all the increasing complexities of distribution.

For this reason there is force in the view that an issuer owes some responsibility to a purchaser, even without direct knowledge of or reliance by the latter on the statements alleged to be untrue or omitted. It seems likely that accountants will enhance their own influence and prestige if they consent to this view, as some of them already do.

But clearly there must be limits. In particular the distinction must be seen between a tangible commodity like a can of food, and an intangible thing like information. The can of food in itself has obvious limitations; it can be definitely identified with its source; it maintains its physical integrity from producer to consumer; it was plainly intended to be eaten by an ultimate consumer, no matter how many intermediaries handled it on the way, and probably it can poison only one family. But information is a more elusive and expansive article; as soon as we get away from the original statements, and begin tracing their "influence," there is no end to the garbling that can ensue, no possibility of identifying the information ultimately consumed with that which the statements first put into circulation, and no limit to the number of people who can claim they were misled by it.

Granting therefore that the makers of financial statements should recognize an obligation to those who may directly or indirectly act upon their statements, the law must find some means of keeping this within reasonable limits.

3. As for the amount of the liability, it is not reasonable to hold issuers and accounts responsible for every interpretation that purchasers may put upon their statements. They are somewhat in the position of Dr. Johnson when he said, "I have found you an argument; I am not obliged to find you an understanding."

"1 8 BoswerL's LIFE or JoHNson, c. IX. 
Accountants are bound to provide financial statements as informative and helpful as possible, but they are not bound to furnish the ability for the complex task of understanding them.

As to whether the misstatement or omission caused the loss, so many other forces can and will operate to bring disaster to an individual company that it is unlikely that the misstatement or omission of any one material fact can be solely responsible for the ultimate outcome of an investment. From this it seems clear that the law bears too heavily on issuers and accountants when it seeks to levy the entire loss upon them, and still more when it seeks to place upon them the burden of proof that the loss was not attributable to the statements complained of.

The use of the phrase "any competent court of jurisdiction" as the authorized place for suit seems unfortunate in matters of this character. If this jurisdiction were restricted to federal courts there would be more probability of the development of a homogeneous treatment of these complex accounting problems, instead of the confusing contradictions likely to result from their handling by the state courts. 